\title{
Determining the Knowledge Level of Parents Relating to Circumcision
}

\author{
๑ Nurdan Akçay Didişen'1, ๑ Atiye Karakul2, ๑ Hamide Nur Çevik Özdemir³
}

${ }^{1}$ Ege University Faculty of Nursing, Department of Child Health and Diseases Nursing, i̇zmir, Turkey

2Tarsus University, Faculty of Health Sciences, Department of Nursing, Mersin, Turkey

${ }^{3}$ Afyonkarahisar Health Sciences University Faculty of Health Science, Department of Child Health and Diseases Nursing, Afyonkarahisar, Turkey

\begin{abstract}
Aim: This study was conducted to determine the knowledge level and opinions of parents regarding circumcision.

Materials and Methods: This descriptive style study was conducted with 258 individuals who were the parents of male patients being treated in the pediatric surgery department of a university hospital. The data of the study were collected through a questionnaire which was designed in line with the literature and given through a face-to-face interviewing method. The data were analyzed by using descriptive statistics with the SPSS 21.0 package program for Windows.

Results: A total of $84.9 \%$ of the parents were the mothers of the children. A total of $70.2 \%$ of the parents stated that they had had their child circumcised by a physician in a hospital setting. Regarding the purpose of circumcision, a total of $27.5 \%$ of the parents stated medical and emergency requirements while $25.6 \%$ of them stated cultural factors. A total of $23.3 \%$ of the parents stated that their children did not want to be circumcised while $57.4 \%$ stated that they had made decision to circumcise together with their spouse. A total of $54.3 \%$ of the parents mentioned that their children experienced pain after circumcision. It was determined that the parents had a moderate level of knowledge regarding the benefits of circumcision, however, most of them had no idea about the practices of circumcision.

Conclusion: Parents emphasized the cultural and medical factors as being the most important factors in the decision to circumcise their child. Parents have a lack of knowledge of circumcision practice, its benefits, and post-circumcision care. Training with the aim of increasing the knowledge of parents regarding circumcision should be planned. Qualitative and quantitative studies on the subject are recommended to be conducted in different regions and with large populations.
\end{abstract}

Keywords: Circumcision, parent, level of knowledge

\section{Introduction}

Circumcision is one of the oldest and most common surgical procedures around the world $(1,2)$. Some factors such as religion, culture, geographical area, race, and ethnicity affect circumcision rates. Although the frequency of circumcision shows differences regionally, it is carried out in almost every region of the world $(3,4)$. According to the World Health Organization report, it is estimated that almost $30-33 \%$ of the men aged 15 and above are circumcised (5). It is a commonly performed practice in some parts of South East Asia, in the Americas, The Philippines, The Middle East, Australia, Israel, South Korea, and regions where there is a high density of Muslim population $(3,6,7)$. The majority of men in Turkey, where most of the population is Muslim, are circumcised (8). 
While circumcision is considered as an expression of cultural identity in certain groups, it is associated with social life, health, and reproductive health in many societies (4). It is accepted as a religious component in Jewish and Muslim societies (2). An average of $25 \%$ men around the world are circumcised due to religious, cultural, medical reasons, and family preferences, according to reports $(9,10)$.

Circumcision is considered as being a symbol of the ability to reproduce and of a child entering into manhood. Circumcision is directly related to health in addition to its religious and traditional connection $(4,8)$. However, there is no clarity regarding the ethical aspect of circumcision. In the literature, while it is thought that child circumcision is unethical and against human rights, it is also stated that it is a beneficial intervention which can prevent some diseases $(2,11)$.

It is stated that circumcision which is performed in the phallic period may lead to acute psychological issues in children. Therefore, circumcision is recommended to be performed before the age of three or after the age of six $(3,12)$. Religious beliefs, traditions, human rights, financial issues, and scientific data are important aspects of discussions regarding circumcision $(8,13)$. Regardless of the meaning that is attached to circumcision, necessary consideration must be given to the fact that this practice should be carried out for men of all age groups in the best conditions and with the least risk $(8,12)$.

Since circumcision is an important surgical procedure, it should be performed by an experienced doctor in a hospital operating room environment $(10,14)$. Circumcisions performed outside the hospital environment may lead to more complications. It is stated that complications happen mostly in the early period after circumcision and the frequency of the complications varies between $0.2 \%$ and $5 \%(15)$. Generally, in eastern societies, circumcisions are performed in environments such as the home or neighborhood health center, which are not suitable for any kind of surgical procedure, and they are carried out by people without any expertise or professional competence $(10,15,16)$. While the complication rate of circumcision performed by trained professionals in developed countries is $5 \%$, it may go up to $95 \%$ in developing countries when the circumcision is performed by a traditional circumciser (10).

There are a limited number of studies that investigate the opinions and knowledge of parents on circumcision. To give information about circumcision to the parents and raise their awareness about this frequently applied procedure is very important. This study was conducted to determine the knowledge level and opinions of parents regarding circumcision.

\section{Materials and Methods}

\section{Study Design}

This study is of a descriptive type. This study was conducted between July 2016 and July 2017 with the parents of boys who were treated in the pediatric surgery wards of a university pediatric hospital. The boys had been previously circumcised or were hospitalized due to an existing circumcision operation. The parents' behaviors, thoughts, and knowledge regarding the circumcision process of their boys were evaluated.

\section{Study Population}

The parents of child patients being treated in the pediatric surgery department formed the population of this study. The sample of the study was 258 individuals who were the parents of male patients between the ages of 0 to 18 years. The inclusion criteria for the study were as follows; being the parent of a previously circumcised male child between the age of 0 to 18 years who was being treated in the pediatric surgery department or being the parent of child who was at that time in the pediatric surgery ward due to a circumcision operation, and being the primary care provider of the child and agreeing to participate in the study.

\section{Data Collection and Instruments}

The questionnaire used in this study was designed by the researchers in line with the literature $(17,18)$. The data were collected through a face-to-face interview method by two of the researchers. The researchers briefed the parents about the study and informed verbal and written consent was obtained from the parents. A "Personal Information Form" and "Circumcision Information Form" were used as the tools to collect data. The personal information form has two sections. The first section includes questions on the socio-demographic parameters of the parents (gender, age, educational background, occupation and income), and the second section includes questions on their behaviors and opinions regarding the practice of circumcision as well as the method they chose for the circumcision of their child. The Circumcision Information Form includes 23 questions which investigate information regarding the parents' level of knowledge on circumcision and care after circumcision.

\section{Statistical Analysis}

The SPSS 21.0 package program for Windows was used to analyze the data. The socio-demographic characteristics of the parents and their knowledge regarding circumcision were evaluated by using descriptive statistical methods (frequency and percentage distribution, mean, standard 
deviation, etc.). Parametric tests (t-test, variance analysis, etc.) were used to analyze the relationship between the parents' socio-demographic characteristics and their total knowledge scores by considering the data structure (normal distribution of data, homogeneity of variance, etc.). The results were evaluated with a $95 \%$ confidence interval and a significance level of $p<0.05$.

In order to conduct this study, the implementation permit (no: 27344949/478-2549) was obtained from the Scientific Ethics Committee of Ege University, and institutional permission was obtained from the children's hospital. In addition, written and verbal informed consent of the parents was obtained before starting the study.

\section{Results}

A total of $84.9 \%$ of the participants were mothers. Parents who were aged 35 years or above comprised $46.1 \%$. A total of $48.8 \%$ of the parents had only primary school graduation and $58.5 \%$ of them were housewives. A total of $55.0 \%$ of the parents stated that their income is equal to their expenses (Table I).

The results regarding the behaviors of parents related to circumcision are presented in Table II. This table includes the parents' experience and knowledge in the process of circumcision of their boys. The doctors performed the circumcision of $82.2 \%$ of the children and a total of $70.2 \%$ of the children were circumcised in a hospital environment. $41.5 \%$ of the parents stated that the child was not briefed before the circumcision, and $57.4 \%$ of parents stated that they made the circumcision decision as a parent of their children. A total of $25.6 \%$ of the parents stated that they had the circumcision of their children done for cultural reasons and $23.6 \%$ of them for medical reasons. After circumcision, $64.7 \%$ of the parents performed the dressings, and $10.5 \%$ kept the foreskin. After circumcision, $54.3 \%$ of children experienced pain, and $8.9 \%$ of them had complications (Table II).

The distribution of the parents' level of knowledge about circumcision is shown in Table III. The mean total score of knowledge is $11.07 \pm 16$ (minimum 2; maximum 18). Regarding the benefits of circumcision, $64.0 \%$ of the parents gave the answer of "the risk of penile cancer decreases" and $48.1 \%$ of them gave the answer of "sexually transmitted diseases are less common". Parents mostly lack knowledge about "No clothes should be worn after circumcision.", "The best period for circumcision is between the ages of 3-6 years", "having a shower immediately after circumcision" and "attaching a baby's diaper". The parents

\begin{tabular}{|c|c|c|c|}
\hline Variables & Groups & $\mathbf{n}$ & $\%$ \\
\hline \multirow{2}{*}{ Gender } & Female & 219 & 84.9 \\
\hline & Male & 39 & 15.1 \\
\hline \multirow{5}{*}{ Age } & 19 years or below & 9 & 3.5 \\
\hline & 20-24 years & 19 & 7.4 \\
\hline & $25-29$ years & 37 & 14.3 \\
\hline & 30-34 years & 74 & 28.7 \\
\hline & 35 year or above & 119 & 46.1 \\
\hline \multirow{5}{*}{ Education status } & Uneducated & 6 & 2.3 \\
\hline & Primary school & 126 & 48.8 \\
\hline & High school & 77 & 29.8 \\
\hline & Undergraduate & 35 & 13.6 \\
\hline & Graduate & 14 & 5.4 \\
\hline \multirow{5}{*}{ Occupation } & Housewife & 151 & 58.5 \\
\hline & Private sector employee & 38 & 14.7 \\
\hline & Self-employed & 17 & 6.6 \\
\hline & Government employee & 42 & 16.3 \\
\hline & Retired & 10 & 3.9 \\
\hline \multirow{3}{*}{ Income status } & Income is less than spending & 93 & 36 \\
\hline & Balanced & 142 & 55 \\
\hline & Income is more than spending & 23 & 9 \\
\hline
\end{tabular}

Table II. Distribution of parents' behavior related to circumcision $(n=258)$

\begin{tabular}{|l|l|l|l|}
\hline Variables & Groups & $\mathbf{n}$ & $\mathbf{\%}$ \\
\hline \multirow{4}{*}{$\begin{array}{l}\text { The person who performed } \\
\text { the circumcision }\end{array}$} & Doctor & 212 & 82.2 \\
\cline { 2 - 4 } & Health technician & 12 & 4.6 \\
\cline { 2 - 4 } & Circumciser & 34 & 13.2 \\
\hline \multirow{4}{*}{ Place of circumcision } & Hospital & 181 & 70.2 \\
\cline { 2 - 4 } & Health center & 13 & 5.0 \\
\cline { 2 - 4 } & Home & 64 & 24.8 \\
\hline \multirow{4}{*}{$\begin{array}{l}\text { Thiefing before circumcision } \\
\text { age }\end{array}$} & Yes & 151 & 58.5 \\
\cline { 2 - 4 } & No & 107 & 41.5 \\
\hline \multirow{5}{*}{$\begin{array}{l}\text { Willingness of children } \\
\end{array}$} & Father & 41 & 15.9 \\
\cline { 2 - 4 } & Mother & 24 & 9.3 \\
\cline { 2 - 4 } & Parental decision & 148 & 57.4 \\
\cline { 2 - 4 } & $\begin{array}{l}\text { Health } \\
\text { professional }\end{array}$ & 35 & 13.5 \\
\cline { 2 - 4 } & Family elders & 10 & 3.9 \\
\hline & Yes & 60 & 23.3 \\
\hline & No & 198 & 76.7 \\
\hline
\end{tabular}




\begin{tabular}{|c|c|c|c|}
\hline \multicolumn{4}{|l|}{ Reasons for circumcision } \\
\hline \multirow{2}{*}{ Cultural reasons } & Yes & 66 & 25.6 \\
\hline & No & 192 & 74.4 \\
\hline \multirow{2}{*}{ Medical reasons } & Yes & 61 & 23.6 \\
\hline & No & 197 & 76.4 \\
\hline \multirow{2}{*}{ Emergency indication } & Yes & 10 & 3.9 \\
\hline & No & 248 & 96.1 \\
\hline \multirow{2}{*}{$\begin{array}{l}\text { Performing the dressing after } \\
\text { circumcision }\end{array}$} & Yes & 167 & 64.7 \\
\hline & No & 91 & 35.3 \\
\hline \multirow{2}{*}{$\begin{array}{l}\text { Observing the presence of } \\
\text { post-circumcision pain }\end{array}$} & Yes & 140 & 54.3 \\
\hline & No & 118 & 45.7 \\
\hline \multirow{2}{*}{ Keeping the foreskin } & Yes & 27 & 10.5 \\
\hline & No & 231 & 89.5 \\
\hline
\end{tabular}

gave the answer of "I have no idea" most to the following topics: "Sexually transmitted diseases are less common in circumcised children", "Neonatal circumcision is not applied to children with a small genital or congenital disorder", "Neonatal circumcision is not applied to children who are born small, cannot maintain body temperature, and cannot be fed", and "bleeding after circumcision is common".

The results of the analysis performed for the comparison of the total scores of the parents' knowledge on circumcision according to socio-demographic characteristics are given in Table IV. No significant relationship was found between the socio-demographic characteristics of the parents and their total knowledge scores.

\section{Discussion}

Parents' opinions and knowledge-levels regarding circumcision were determined with this study. Circumcision has been a common surgical procedure since ancient times $(4,19)$. This study determined that approximately one-fourth of the parents had their children circumcised due to cultural factors. Sardi and Livingston (20) stated in their study that parents had their children circumcised primarily for cultural and personal expectations and then for health reasons. Similarly, in the study of Rizalar et al. (8), 69.3\% of the parents stated religious beliefs as the reason for circumcision while $29.1 \%$ of them stated cultural factors. Other studies in the literature also stated that almost all parents had their children circumcised due to religious and cultural reasons $(19,21)$. The results of our study show similarities with the literature. The results reveal once again that cultural factors are an important component of circumcision practice. The proportional differences in the results of the research may be related to the size of the study samples, participants living in different regions, and having different traditional structures. While circumcision is considered a religious component in Muslim and Jewish societies (2), it is associated with medical reasons and health in western societies (7). Waskett (22) stated in his report that circumcision is becoming more and more common around the world, however, it is being preferred for health and medical purposes, more than for the cultural and religious reasons. It is stated in another study that some of parents had their children circumcised because of beliefs related to sexuality and cosmetics (23). Similar to studies in the literature, this study's findings show that almost 25\% of the parents had their children circumcised due to medical reasons, while a total of $4 \%$ of them were due to emergency medical indications. Our study results are consistent with the literature.

Since circumcision is a surgical procedure, it should be performed by specialists following aseptic techniques $(4,16)$. It was determined in this study that more than half of the parents had their children circumcised by a doctor in a hospital setting. In another similar study, 57.9\% of the parents stated that they preferred to have their children circumcised by a doctor in a public hospital (23). According to the study of Koç et al. (24), 63.5\% of the families had their children circumcised in a hospital setting. Although literature information and study results show that the vast majority of families have their children circumcised safely in a hospital setting, there are also reports that in developing countries and eastern communities, circumcision is still performed at home, in neighborhood health centers, and in crowded areas (such as mass circumcision ceremonies). It is also stated in research reports that in developing countries, circumcision continues to be conducted by nonprofessional people, who are referred to as "circumcisers" $(7,22)$. The families' lack of knowledge on circumcision, their consideration of circumcision as a simple operation, economic factors, family rituals, and the density of health institutions might be considered as the reasons leading to these situations.

Since circumcision is a surgical procedure, the risk of developing complications may increase if it is not performed under suitable conditions $(4,25)$. In this study, parents stated that $10 \%$ of the children developed complications $(4,25)$. Similarly, Altunkol et al. (25) mentioned that $8.7 \%$ of the patients that were circumcised developed complications either minor or major. Also, Türkan et al. (26) reported in their study that $12.0 \%$ of the children had 
Table III. Distribution of the parents' level of knowledge about circumcision $(n=258)$

\begin{tabular}{|c|c|c|c|c|c|c|}
\hline \multirow{2}{*}{ Statements } & \multicolumn{2}{|c|}{ Know } & \multicolumn{2}{|c|}{ Don't know } & \multicolumn{2}{|c|}{ No idea } \\
\hline & $\mathbf{n}$ & $\%$ & n & $\%$ & $\mathbf{n}$ & $\%$ \\
\hline Urinary tract infections are more common in circumcised children. & 138 & 53.5 & 34 & 13.2 & 86 & 33.3 \\
\hline $\begin{array}{l}\text { Circumcision leads to better penile cleansing and the rate of penile cancer in } \\
\text { children with circumcision decreases. }\end{array}$ & 165 & 64.0 & 7 & 2.7 & 86 & 33.3 \\
\hline Sexually transmitted diseases are less common in circumcised children. & 124 & 48.1 & 10 & 3.9 & 124 & 48.1 \\
\hline $\begin{array}{l}\text { Circumcision is used as a treatment for conditions such as tightness in the } \\
\text { foreskin, bonded foreskin, and paraphimosis. }\end{array}$ & 199 & 77.1 & 12 & 4.7 & 47 & 18.2 \\
\hline In our country, males must be circumcised to get married. & 207 & 65.9 & 46 & 17.8 & 42 & 16.3 \\
\hline Circumcision may lead to emotional stress in children. & 170 & 65.9 & 46 & 17.8 & 42 & 16.3 \\
\hline No clothes should be worn after circumcision. & 90 & 34.9 & 117 & 45.3 & 51 & 19.8 \\
\hline $\begin{array}{l}\text { Neonatal circumcision is not applied to children with small genitals or a } \\
\text { congenital disorder. }\end{array}$ & 65 & 25.2 & 27 & 10.5 & 166 & 64.3 \\
\hline $\begin{array}{l}\text { Neonatal circumcision is not applied to children who are born small, cannot } \\
\text { maintain body temperature, or cannot be fed. }\end{array}$ & 52 & 20.2 & 41 & 15.9 & 165 & 64.0 \\
\hline The child who is entering the adolescence period cannot be circumcised. & 99 & 38.4 & 71 & 27.5 & 88 & 34.1 \\
\hline $\begin{array}{l}\text { Children with hemophilia should not be circumcised without taking the necessary } \\
\text { precautions. }\end{array}$ & 193 & 74.8 & 19 & 7.4 & 46 & 17.8 \\
\hline $\begin{array}{l}\text { Complications will develop after circumcision if the aseptic conditions are not } \\
\text { maintained. }\end{array}$ & 170 & 65.9 & 26 & 10.1 & 62 & 24.0 \\
\hline The younger the child is, the more difficult the circumcision is. & 119 & 46.1 & 69 & 26.7 & 70 & 27.1 \\
\hline The most common thing after circumcision is bleeding. & 105 & 40.7 & 43 & 16.7 & 110 & 42.6 \\
\hline Circumcision should not be performed in the neonatal period. & 118 & 45.7 & 67 & 26.0 & 73 & 28.3 \\
\hline The best period for circumcision is between the age of 3-6 years. & 76 & 29.5 & 102 & 39.5 & 80 & 31.0 \\
\hline The child can ride a bicycle the day after circumcision. & 222 & 86.0 & 14 & 5.5 & 22 & 8.5 \\
\hline The child can take a shower immediately after circumcision. & 26 & 10.1 & 181 & 70.2 & 51 & 19.8 \\
\hline Having a shower every day after circumcision speeds up the recovery. & 38 & 14.7 & 121 & 46.9 & 99 & 38.4 \\
\hline If the baby is using a diaper, it should not be changed frequently. & 117 & 45.3 & 98 & 38.0 & 43 & 16.7 \\
\hline If the baby is using a diaper, it should be attached loosely. & 20 & 7.8 & 198 & 76.7 & 40 & 15.5 \\
\hline Straining leads to increased bleeding and constipation in circumcised children. & 87 & 33.7 & 37 & 14.3 & 134 & 51.9 \\
\hline $\begin{array}{l}\text { Since the sense of pain does not develop in the newborn, circumcision can be } \\
\text { performed without anesthesia. }\end{array}$ & 41 & 15.9 & 80 & 31.0 & 137 & 53.1 \\
\hline
\end{tabular}

complications developing after circumcision. The results of this study show similarities with the complication rates in the literature. Performing circumcision in settings not suitable for surgical procedures, circumcision being performed by non-professionals, and the parents' lack of knowledge on post-circumcision care might be the leading factors for the development of complications. Moreover, it is widely believed that hastily performing circumcision when performed in a mass environment might lead to the development of complications as well as infections.

Although circumcision is considered to be a sociological need, it is a topic of discussion on medical ethics and patient rights due to its possible psychological effects on male children. Especially, there are different opinions on the appropriate age for circumcision $(27,28)$. The findings of our study determined that almost two-thirds of the children were not willing to be circumcised, while more than half of the parents stated that they decided on the circumcision. Similar studies in the literature mention that parents decide on circumcision $(24,29)$. According to the results of this study, although parents have the biggest determining element on circumcision, briefing the child about circumcision and getting his opinion should be considered in terms of personal rights and ethics. 
Table IV. Comparison of parents' total scores on circumcision knowledge levels by socio-demographic characteristics

\begin{tabular}{|c|c|c|c|c|}
\hline Variables & Groups & $\mathbf{n}$ & $X \pm S D$ & $\begin{array}{l}\text { Statistical } \\
\text { value }\end{array}$ \\
\hline Gender & $\begin{array}{l}\text { Female } \\
\text { Male }\end{array}$ & $\begin{array}{l}219 \\
39\end{array}$ & $\begin{array}{l}43.76 \pm 6.81 \\
43.79 \pm 6.74\end{array}$ & $\begin{array}{l}\text { t: } 0.02^{*} \\
\text { p: } 0.98^{*}\end{array}$ \\
\hline \multirow{5}{*}{ Age } & 19 year or below & 9 & $40.66 \pm 6.02$ & \multirow{5}{*}{$\begin{array}{l}\text { F: } 0.57^{* *} \\
\text { p: } 0.68\end{array}$} \\
\hline & 20-24 years & 19 & $43.94 \pm 6.84$ & \\
\hline & $25-29$ years & 37 & $44.13 \pm 5.21$ & \\
\hline & $30-34$ years & 74 & $43.48 \pm 6.05$ & \\
\hline & 35 year or above & 119 & $44.04 \pm 7.67$ & \\
\hline \multirow{5}{*}{$\begin{array}{l}\text { Education } \\
\text { status }\end{array}$} & Uneducated & 6 & $42.66 \pm 5.53$ & \multirow{5}{*}{$\begin{array}{l}\text { F: } 1.67^{* *} \\
\text { p: } 0.15\end{array}$} \\
\hline & Primary school & 126 & $44.34 \pm 6.88$ & \\
\hline & High school & 77 & $42.17 \pm 1.21$ & \\
\hline & Undergraduate & 35 & $40.50 \pm 7.06$ & \\
\hline & Graduate & 14 & $43.77 \pm 6.78$ & \\
\hline \multirow{5}{*}{ Occupation } & Housewife & 151 & $43.77 \pm 6.49$ & \multirow{5}{*}{$\begin{array}{l}\mathrm{F}: 1.61^{* *} \\
\mathrm{p}: 0.17\end{array}$} \\
\hline & $\begin{array}{l}\text { Private sector } \\
\text { employee }\end{array}$ & 38 & $45.55 \pm 7.84$ & \\
\hline & Self employed & 17 & $42.11 \pm 6.78$ & \\
\hline & $\begin{array}{l}\text { Government } \\
\text { employee }\end{array}$ & 42 & $42.33 \pm 6.78$ & \\
\hline & Retired & 10 & $45.80 \pm 2.97$ & \\
\hline \multirow{3}{*}{$\begin{array}{l}\text { Income } \\
\text { status }\end{array}$} & $\begin{array}{l}\text { Income is less } \\
\text { than spending }\end{array}$ & 93 & $45.52 \pm 6.97$ & \multirow{3}{*}{$\begin{array}{l}\text { F: } 1.80^{* *} \\
\text { p: } 0.16\end{array}$} \\
\hline & Balanced & 142 & $43.10 \pm 6.43$ & \\
\hline & $\begin{array}{l}\text { Income is more } \\
\text { than spending }\end{array}$ & 23 & $44.35 \pm 7.19$ & \\
\hline \multirow{3}{*}{$\begin{array}{l}\text { The person } \\
\text { who } \\
\text { performed } \\
\text { the } \\
\text { circumcision }\end{array}$} & Doctor & 212 & $43.75 \pm 6.76$ & \multirow{3}{*}{$\begin{array}{l}\text { F: } 1.47^{* *} \\
\text { p: } 0.86\end{array}$} \\
\hline & Health technician & 12 & $42.91 \pm 6.81$ & \\
\hline & Circumciser & 34 & $44.14 \pm 7.11$ & \\
\hline
\end{tabular}

Circumcision might be a painful, traumatic experience that is perceived as emotionally negative $(29,30)$. There are a few studies about the prolonged psychological effects of male circumcision. Goldman (31) stated in their study that circumcised males generally experience feelings of anger, embarrassment, grief, instability, and of being abused. Therefore, circumcision is recommended to be performed at the ages when the psychological effects are minimal and by a doctor (28). It was determined in this study that parents do not have sufficient knowledge of the appropriate age for circumcision. Similarly, in other studies in the literature, parents did not know much about the appropriate age levels for circumcision $(24,29,32)$. These studies mostly state that children are circumcised at school age. Özkan et al. (33) stated in their study that $44.8 \%$ of circumcisions were conducted while the children were in the phallic period. Circumcision is a condition that significantly affects a child's inner world and sense of self. Therefore, when determining the age of circumcision, the psychological effect of the circumcision on the child should be taken into consideration, and children's emotional reactions and their perceptions should be evaluated (15). Especially, circumcision that is conducted between the ages of 3 to 6 years might lead to a negative experience for the children as, during this period, the children's sexual identity begins to develop and their genitals start to have meaning and value from the child's point of view. Especially, they might experience fear of losing their genitals (castration) during this period. Due to these reasons, it is recommended that circumcision is conducted before the age of 3 or after the age of 6 years $(27,28)$. Also, it is thought that families prefer to carry out circumcision during the school-age after children develop concrete perceptions so that their children can remember it as a pleasant ritual.

It was determined that the parents in this study did not have sufficient knowledge regarding the benefits of circumcision. Approximately half of the parents have wrong information regarding the practice of neonatal circumcision. There is scientific evidence on the possible medical benefits of neonatal circumcision. However, this evidence is not sufficient to recommend neonatal circumcision as a routine practice (34). It is stated that neonatal circumcision decreases the risk of urinary tract infections, HIV, and other sexually transmitted diseases and the development of carcinoma in the penis $(34,35)$. In a meta-analysis study in which 1,000 circumcised adults in Africa were examined, it was reported that circumcision reduces the risk of HIV by $38-64 \%$ (11). A low level of education among the parents and the fear of newborns being harmed might affect the knowledge level of the parents regarding neonatal circumcision. Besides, the parents' lack of knowledge on a child's development periods as well as not knowing about sexual identity acquisition of the child in the phallic period may cause them to have difficulties with the decision of circumcision age.

Correctly applied post-circumcision care is effective in reducing the risk of complications after circumcision (36). According to the results of this study, parents have a moderate level of knowledge of post-circumcision care and procedures. In contrast to our results, a study conducted 
with mothers revealed that the knowledge level of the mothers on post-circumcision care and complications was above average (21). It was reported in studies investigating the post-circumcision status that bleeding, insufficient circumcision, fistula, and infection are the complications observed frequently $(16,33)$. These results reveal the necessity of following aseptic techniques for care both during the circumcision procedure and in the post-circumcision period. It is thought that it is necessary to provide education on post-circumcision care to mothers, as they are often the primary caretakers, in order to manage successful postcircumcision care and reduce the risk of infection.

\section{Study Limitations}

This study had some limitations. This study was conducted with the parents of male patients being treated in the pediatric surgery department of a university hospital. The data was limited to the level of knowledge of parents regarding circumcision and provided information about the current situation. During data collection, 20 participants did not want to complete the study, and therefore, their data were excluded from the study. The targeted number of samples was reached in the general framework and a reliable and high rate of response was received from the participants. Applying valid and reliable assessment tools which are used to measure the knowledge of individuals regarding circumcision in the study could contribute to a clearer demonstration of the effectiveness of the results.

\section{Conclusion}

Circumcision is a process that includes religious, traditional, and medical dimensions. In addition, this process has an important effect on a child's psychology and their sense of self. The results of this study revealed that parents do not have sufficient or accurate information on circumcision. Also, a child's opinion is not taken into account when making decisions on circumcision and parents have the final say on these decisions. Due to this, health professionals (doctors, nurses, primary care physicians, etc.) should provide the necessary education to the parents and society on circumcision, and awareness should be increased with educational activities. It is recommended to conduct qualitative and quantitative studies in larger sample groups and in different regions to evaluate families' knowledge and opinions on circumcision. In addition, qualitative studies evaluating the children's perception of circumcision should be conducted in order to take their opinions into consideration.

\section{Acknowledgement}

The authors are grateful to acknowledge all participating parents in this study.

\section{Ethics}

Ethics Committee Approval: This study was approved by the Ege University Faculty of Nursing, Scientific Ethics Committee of the University (approval number: 27344949/478-2549) and by the clinic where the study was conducted.

Informed Consent: Written informed consent was obtained from the participants before enrollment.

Peer-review: Externally and internally peer-reviewed.

\section{Authorship Contributions}

Concept: N.A.D., A.K., H.N.Ç.Ö., Design: N.A.D., A.K., H.N.Ç.Ö., Data Collection or Processing: H.N.Ç.Ö., A.K., Analysis: A.K., Interpretation: A.K., H.N.Ç.Ö., Literature Search: N.A.D., A.K., H.N.Ç.Ö., Writing-review: H.N.Ç.Ö., A.K., Editing, and supervision: N.A.D., A.K., H.N.Ç.Ö.

Conflict of Interest: No conflict of interest was declared by the authors.

Financial Disclosure: The authors declared that this study received no financial support.

\section{References}

1. Hayashi Y, Kojima Y, Mizuno K, Kohri K. Prepuce: phimosis, paraphimosis, and circumcision. ScientificWorldjournal 2011; 11:289-301.

2. UNAIDS. Neonatal and child male circumcision: A global review. 2010. Available from: https://www.who.int/hiv/pub/ malecircumcision/neonatal_child_MC_UNAIDS.pdf

3. İzgi CM. Ethical evaluation of non-therapeutic male circumcision. Turkish Journal of Psychiatry 2014; 25:204-12.

4. Koçkaya G. Tek kullanımlık sünnet aletlerinin sağlık teknolojisi değerlendirme analizi. Ankara STD 2018;03/00. Erişim adresi: https://shgm.saglik.gov.tr/TR-53887/tek-kullanimlik-sunnetaletlerinin-saglik-teknolojisi-degerlendirme-analizi-std-raporu. html

5. WHO. Male circumcision: global trends and determinants of prevalence, safety and acceptability 2007. Available from: https://apps.who.int/iris/handle/10665/43749.

6. Sivaslı E, Bozkurt Ai, Ceylan H, Coşkun Y. Knowledge, attitude and behavior of parents regarding circumcision in Gaziantep. Çocuk Sağlığı ve Hastalıkları Dergisi 2003; 46:114-8.

7. UNAIDS. Male circumcision, global trends and determinants of prevalence, safety and acceptability. 2007. Available from: https://data.unaids.org/pub/report/2007/jc1360_male_ circumcision en.pdf

8. Rızalar S, Büyük ET, Yıldırım N. Children's perspectives on the medical and cultural aspects of circumcision. Iran / Pediatr 2017; 27:e7561. 
9. Afsari M, Beasley SW, Heckert K. Attitudes of Pacific parents to circumcision of boys. Pac Health Dialog 2002; 9:29-33.

10. Çevik M, Boleken ME, Kaya H, Öcal S. Amputation of the glans penis and hypospadias after circumcision: a case report. Ulusal Cerrahi Derg 2011; 27:246-8.

11. Siegfried N, Muller M, Deeks J), Volmink J. Male circumcision for prevention of heterosexual acquisition of HIV in men. Cochrane Database Syst Rev 2009; CD003362.

12. Yılmaz Y, Özsoy SA, Ardahan M. Review of behaviors and knowledge levels of mothers about circumcision. Ege Journal of Medicine 2008; 47:93-101.

13. Gerharz E, Haarmann C. The first cut is the deepest? Medicolegal aspects of male circumcision. BJU Int 2000; 86:332-8.

14. Üstüner Top F, Esüntimur Y, Uykan L, Aydın Pekdemir E. The knowledge, behaviour and attitude about of circumcision in families in Giresun. Çocuk Dergisi 2008; 8:166-71.

15. Türk E. Should circumcision during the summer months be a nightmare for pediatric surgeons? The views and practice of a pediatric surgeon working at a state hospital? Çocuk Cerrahisi Dergisi 2010; 24:82-8.

16. Yapanoğlu T, Aksoy Y, Atmaca AF, Ziypak T, Cesur M, Özbey i. Complications of Circumcision in our region. Türk Üroloji Derg 2004; 30:441-5.

17. Cankorkmaz L, Çetinkaya S, Köylüoğlu G. General practitioner knowledge levels about circumcision. Balkan Med I 2011; 28:2648.

18. Çataklı T, Yazarlı E, Yener F, Bilge YD. Knowledge levels about circumcion of mother admitted to a hospital. Erciyes Med I 2012; 34:116-20

19. Corduk N, Unlu G, Sarioglu-Buke A, Buber A, Savran B, Zencir M. Knowledge, attitude and behaviour of boys and parents about circumcision. Acta Paediatr 2013; 102:e169-73.

20. Sardi L, Livingston K. Parental decision making in male circumcision. MCN Am J Matern Child Nurs 2015; 40:110-5.

21. Özkan $\mathrm{H}$, Karakoç $\mathrm{H}$, Tedik SE, Yapanoğlu T. Identification of knowledge levels of mothers about circumcision. Anadolu Hemşirelik ve Sağlık Bilimleri Dergisi 2019; 22:1-7.

22. Waskett JH. Global circumcision rates. Circumcision Independent Reference and Commentary Service. 2014. https:// web.archive.org/web/20120805153305/http://www.circs.org/ index.php/Reviews/Rates/Global
23. Leung MVY, Tang PMY, Chao NSY, Liu KKW. Hong Kong Chinese parents' attitudes towards circumcision. Hong Kong Med I 2012; 18:496-501.

24. Koç F, Akşit $\mathrm{S}$, Koç $\mathrm{G}$, et al. Parental attitudes and practices about circumcision in İzmir. J Univers Surg 2013; 2:1-6.

25. Altunkol A, Abat $D$, Şener NC, Ünal U, Evliyaoğlu Y, Yeni E. Retrosprective analysis of circumcision and complications in municipal hospital. J Clin Anal Med 2015; 6:341-4.

26. Türkan S, Kalkan M, Şahin C. Genital anomaly and complication rates among circumcised children in Kastamonu region. J Pediatr Urol 2011; 37:43-6.

27. Kalkan M, Toraman AR, Türkan S. A comparison of sense of self and self-esteem in uncircumcised men over the age of 20 to those who were circumcised during childhood. General Urology 2010; 36:411-7.

28. Şengül $H$, Bulut $A$. Investigation of sunnet and patient rights denied in male children. J Soc Hum Sci Res 2018; 5:10-5.

29. Gülaçtı $G B$, Pekaslan E, Acar ş. Content analysis of college students' autobiographical memories about circumcision. DTCF Derg 2016; 56:355-73.

30. Sahin F, Beyazova $U$, Aktürk A. Attitudes and practices regarding circumcision in Turkey. Child Care Health Dev 2003; 29:275-80.

31. Goldman R. The psychological impact of circumcision. BJU Int $1999 ; 83: 93-102$

32. Rediger C, Muller A). Parents' rationale for male circumcision. Can Fam Physician 2013; 59:e110-5.

33. Özkan A, Özorak A, Oruç M. Retrospective investigation of complications in nineteen hundred cases of circumcision. Konuralp Tıp Dergisi 2012; 4:8-12.

34. American Academy of Pediatrics Task Force on Circumcision. Male circumcision. Pediatrics 2012; 130:e756-85. doi: 10.1542/ peds.2012-1990.

35. Morris BJ, Bailey RC, Klausner JD, et al. Review: a critical evaluation of arguments opposing male circumcision for HIV prevention in developed countries. AIDS Care 2012; 24:1565-75.

36. Balkan E, Kılıç N. Sünnet ve komplikasyonları. Curr Pediatr Rep 2005; 2:22-3. 